Letter to the Editor

\title{
Number of ocular syphilis cases creeps to record high
}

Daini Ong MBBS(Hons) BMedSci(Hons), ${ }^{1,2,3}$ J ason J Ong PhD FAChSHM ${ }^{4}$ and Lyndell

\author{
L Lim FRANZCO DMedSci ${ }^{1,2,3}$
}

${ }^{1}$ Centre for Eye Research Australia

${ }^{2}$ the Royal Victorian Eye and Ear Hospital, Victoria, Australia

${ }^{3}$ Ophthalmology, Department of Surgery, University of Melbourne, Melbourne,

Australia

${ }^{4}$ Melbourne Sexual Health Centre, Alfred Health, Victoria, Australia

Correspondence: Lyndell L Lim, Centre for Eye Research Australia

32 Gisborne St, East Melbourne 3002, Australia

Email: limllp@unimelb.edu.au

Received 22 February 2017; accepted 21 May 2017

Conflict of interest: None

Funding sources: Research fund of the Royal Victorian Eye and Ear Hospital

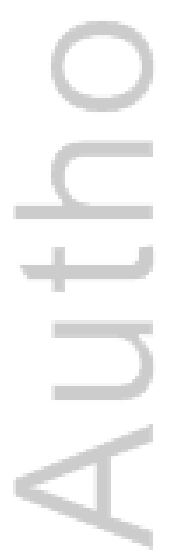

This is the author manuscript accepted for publication and has undergone full peer review but has not been through the copyediting, typesetting, pagination and proofreading process, which may lead to differences between this version and the Version of Record. Please cite this article as doi: 10.1111/ceo.13021

This article is protected by copyright. All rights reserved. 
We would like to bring to the readers' attention the sharp increase in incidence of syphilis in Australia and the corresponding increase in the number of ocular syphilis presentations to the Royal Victorian Eye and Ear Hospital (RVEEH) over the past 10 years.

The incidence of syphilis notifications to the national notifiable disease surveillance system has tripled in the past 10 years in Australia, from approximately 4.3 per 100,000 in 2006 to 13.4 per 100, 000 in 2016. ${ }^{1}$ We report a corresponding increase in ocular syphilis cases in RVEEH over the same period (Figure 1). Our internal audit has shown an increase from 2 cases per year in 2006 to 9 cases in 2016. This is out of proportion to population growth, which increased from 5.13 million in 2006 to 5.94 million in 2016. The estimated prevalence rate of ocular syphilis among syphilis cases is estimated to be $0.6 \% .^{2}$

Ocular syphilis with its varied presentations (Figure 2), has been previously described. ${ }^{3,4}$ In light of the current syphilis epidemic in Australia, we would like to remind the ophthalmic community that we will likely continue to see increasing numbers of ocular syphilis cases and thus a high index of suspicion is needed. We recommend that ophthalmologists routinely test for syphilis in newly diagnosed uveitis cases, take a sexual history to identify the high risk group of men who have sex with men, and also test for HIV in confirmed cases of syphilis, given the high rates of co-infection. ${ }^{2}$ 


\section{REFERENCES}

1. Australian National Notifiable Diseases Surveillance. Number of notifications of syphilis < 2 years. Accessed April 2017. Available from: http://www9.health.gov.au/cda/source/rpt_2.cfm

2. Oliver SE, Aubin M, Atwell L et al. Ocular Syphilis - Eight Jurisdictions, United States, 2014-2015. MMWR Morb Mortal Wkly Rep 2016; 65: 1185-8.

3. - Northey LC, Skalicky SE, Gurbaxani A, McCluskey PJ. Syphilitic uveitis and optic neuritis in Sydney, Australia. Br J Ophthalmol 2015; 99: 1215-9.

4. Hughes EH, Guzowski M, Simunovic MP, Hunyor AP, McCluskey P. Syphilitic retinitis and uveitis in HIV-positive adults. Clin Exp Ophthalmol 2010; 38: 851-6. 


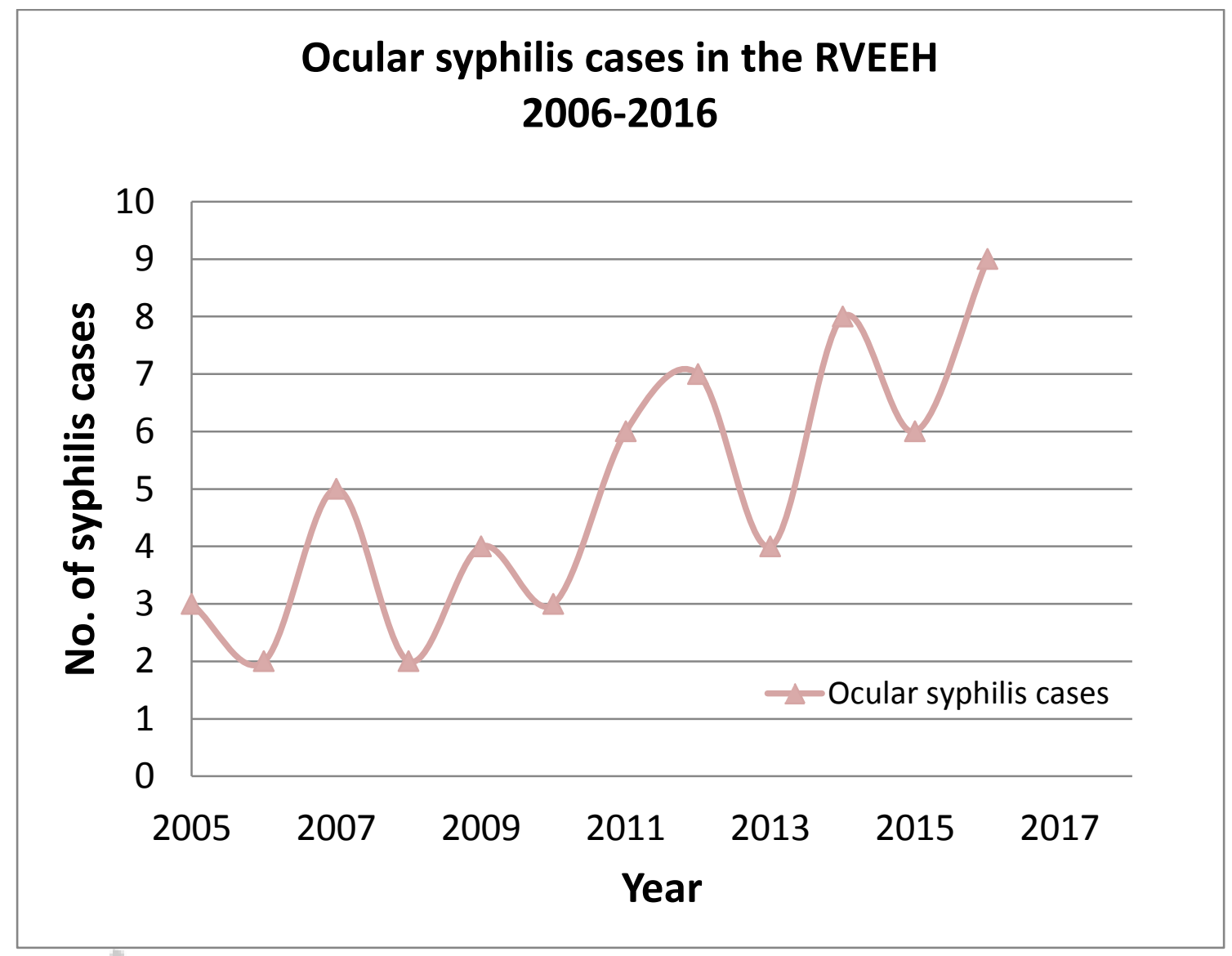

Figure 1: ocular syphilis cases presented the RVEEH over 10 years 

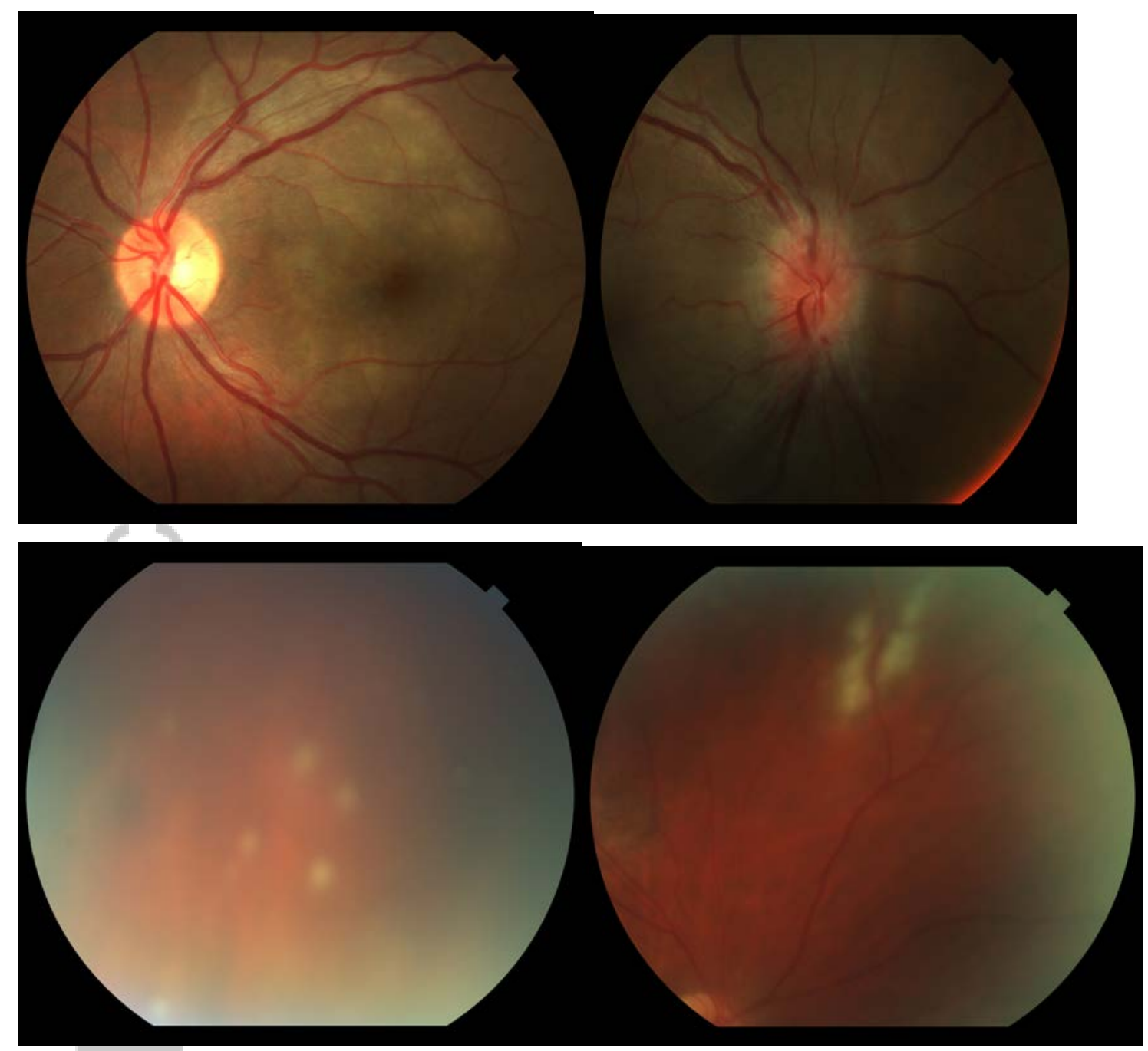

Figure 2: Examples of syphilis as the great masquerade: posterior placoid chorioretinitis (top left); disc swelling (top right); punctate inner retinitis (bottom left); perivascular retinitis (bottom right). 


\section{University Library}

\section{- M M I E E R VA A gateway to Melbourne's research publications}

Minerva Access is the Institutional Repository of The University of Melbourne

Author/s:

Ong, D;Ong, JJ;Lim, LL

Title:

Number of ocular syphilis cases creeps to record high

Date:

2018-01-01

Citation:

Ong, D., Ong, J. J. \& Lim, L. L. (2018). Number of ocular syphilis cases creeps to record high. CLINICAL AND EXPERIMENTAL OPHTHALMOLOGY, 46 (1), pp.98-99. https:// doi.org/10.1111/ceo.13021.

Persistent Link:

http://hdl.handle.net/11343/293359 